\title{
OSTIAL VERSUS TRUNCAL RENAL ARTERY STENOSIS: PREDICTOR OF LARGE ARTERY ATHEROSCLEROSIS SEVERITY AND HIGHER MORTALITY
}

\author{
Dražen Perkov ${ }^{1}$, Vedran Premužić ${ }^{2}$, Ranko Smiljanić ${ }^{1}$, Ljiljana Fodor ${ }^{3}$, \\ Savko Dobrota ${ }^{1}$ and Bojan Jelaković ${ }^{2}$ \\ ${ }^{1}$ Department of Diagnostic and Interventional Radiology, Zagreb University Hospital Centre, \\ University of Zagreb School of Medicine, Zagreb, Croatia; \\ ${ }^{2}$ Department of Nephrology, Hypertension, Dialysis and Transplantation, Zagreb University Hospital Centre, \\ University of Zagreb School of Medicine, Zagreb, Croatia; \\ ${ }^{3}$ Department of Nephrology and Dialysis, Sestre milosrdnice University Hospital Centre, \\ University of Zagreb School of Medicine, Zagreb, Croatia
}

\begin{abstract}
SUMMARY - The aim of this study was to determine arterial stiffness and the effect of stenting in patients with renal artery stenosis. We hypothesized that ostial renal artery stenosis is not only a marker of more pronounced atherosclerosis of large arteries, but is also a predictor of higher cardiovascular mortality. We enrolled 33 patients with renal artery stenosis refractory to pharmacological treatment and divided them according to the renal artery stenosis location, ostial and truncal (23 vs. 10 patients). We analyzed patient survival at five-year follow up. After the intervention and at sixmonth follow up, there was a significant decrease in blood pressure values, as well as in pulse wave velocity (PWV) and augmentation index. PWV was significantly lower in patients with truncal renal artery stenosis and these patients were significantly younger. Twelve patients with ostial and one patient with truncal renal artery stenosis $(52 \%$ vs. $10 \%, \mathrm{p}<0.001)$ died from cardiovascular events. Our study is the first to confirm the predictive role of PWVand arterial stiffness in patients with renal artery stenosis, especially ostial one, and to emphasize its ability of detecting future higher incidence of cardiovascular events.
\end{abstract}

Key words: Renal artery obstruction; Atherosclerosis; Pulse wave analysis; Vascular stiffness; Mortality; Survival

\section{Introduction}

The incidence of renal artery stenosis is high in $\mathrm{pa}^{-}$ tients with advanced atherosclerosis. Patients with peripheral arterial disease, coronary arterial disease, uncontrolled arterial hypertension or renal insufficiency have an increased risk of renal artery stenosis ${ }^{1-3}$. Myo-

Correspondence to: Dražen Perkov, $M D, P h D$, Department of Diagnostic and Interventional Radiology, Zagreb University Hospital Centre, University of Zagreb School of Medicine, Kišpaticeva 12, HR-10000 Zagreb, Croatia

E-mail: drazen.perkov@outlook.com

Received October 2, 2018, accepted January 28, 2019 cardial infarction, stroke, peripheral arterial disease and cardiovascular death are strongly correlated with renal artery stenosis, which is an independent predictor of these events ${ }^{4-6}$. The severity of renal artery stenosis is strongly correlated with higher mortality, especially in patients with bilateral renal artery stenosis ${ }^{7}$, or in patients with accompanying coronary arterial disease. Arterial stiffness is a marker of atherosclerosis and is associated with hypertension, especially when untreated $^{8,9}$. The predictive value of arterial stiffness, which is a marker of target organ damage, is well established for cardiovascular events and morbidity ${ }^{8-10}$, but data on arterial stiffness in patients with renal ar- 
tery stenosis are rather scarce ${ }^{11}$. Renal artery stenosis is a marker of advanced atherosclerosis ${ }^{12}$, as well as arterial stiffness, with associated implications for future cardiovascular events and patient mortality. Recent trials failed to prove the advantages of stenting compared to intensive medical therapy ${ }^{13}$, but endovascular intervention should be considered in patients with significant stenosis and severe symptoms ${ }^{14,15}$. Renal artery stenosis is often seen in older patients with aortosclerosis and is often located in the ostium with extension to the aorta. Treatment of ostial renal artery stenosis is associated with higher restenosis rates and lower procedural success ${ }^{16}$. Regarding the different anatomic locations of renal artery stenosis and possible correlation of ostial stenosis with atherosclerosis of large arteries compared to truncal stenosis ${ }^{17}$, we hypothesized that ostial renal artery stenosis is a marker of more pronounced atherosclerosis of large arteries. Therefore, the aim of this study was to determine arterial stiffness in patients with functional grade III renal artery stenosis which is defined as stenosis with resistant hypertension, abnormal renal function or volume overload ${ }^{14}$, and the effect of stenting on markers of arterial stiffness.

\section{Patients and Methods}

\section{Study patients}

In this retrospective longitudinal study, we enrolled 33 patients with atherosclerotic renal artery stenosis that was refractory to pharmacological treatment. These patients were divided into two subgroups according to the renal artery stenosis location, ostial and truncal (23 vs. 10 patients). Both subgroups of patients were referred to our outpatient clinic between February 2009 and August 2011.

The inclusion criteria were patients older than 18 years, uncontrolled hypertension (office blood pressure $(B P) \geq 140 / 90 \mathrm{~mm} \mathrm{Hg}$ despite using more than two antihypertensives), kidney length $\geq 7 \mathrm{~cm}$, chronic kidney disease (CKD) stages $\geq 4$, and renal artery stenosis $\geq 60 \%$ confirmed by digital subtraction angiography (DSA) and based on visual estimation. The exclusion criteria were intrarenal artery resistance index $\geq 0.80$, bilateral stenosis of renal arteries, fibromuscular dysplasia, occlusion or dissection of renal artery, pregnancy, or a history of stroke, acute heart failure, pulmonary edema, or myocardial infarction within six months of the study initiation. A written informed consent was obtained from each participant and the study protocol was approved by the local Ethics Committee. Each patient underwent complete clinical and laboratory workup at admission and at six-month follow up. Renal function was defined as estimated creatinine clearance (estimated glomerular filtration rate, eGFR, $\mathrm{mL} / \mathrm{min}$ ), which was estimated using the simplified Modification of Diet in Renal Disease equation.

\section{Arterial blood pressure, pulse wave velocity and augmentation index measurements}

Office brachial BP and heart rate were measured using the M6 Comfort device Intellisense (Omron, Kyoto, Japan) $24 \mathrm{~h}$ and $48 \mathrm{~h}$ before stenting, and six months after the intervention. The mean value of three measurements was used on further analysis. The Arteriograph device (TensioMed Ltd., Budapest, Hungary) was used to determine the indices of arterial stiffness, i.e. pulse wave velocity (PWV), augmentation index (AIx) and central systolic BP, both before revascularization and at six-month follow up. We analyzed patient survival at five-year follow up.

\section{Diagnostic and endovascular procedure}

All study patients underwent baseline kidney ultrasound and color Doppler ultrasound examination. Localization, extension and severity of renal artery stenosis was determined by multidetector computed tomography (MDCT) or magnetic resonance (MR) angiography, and later confirmed by DSA. Initial laboratory workup and measurements were performed on the day before the endovascular intervention and patients received $325 \mathrm{mg}$ of aspirin and $300 \mathrm{mg}$ of clopidogrel thereafter. After the endovascular intervention, patients were administered $100 \mathrm{mg}$ aspirin for life and $75 \mathrm{mg}$ of clopidogrel for three months. All invasive diagnostic and interventional procedures were performed using a non-ionic iodine contrast agent and conducted in local anesthesia, conscious sedation and analgesia. The access site was either femoral or brachial artery. All procedures were performed through the $7 \mathrm{~F} \mathrm{RDC}$ or $\mathrm{HS}$ introducer guide catheter (Vista BriteTip IG, Cordis, USA) for femoral access and 6F Special guiding catheter (Vista BriteTip, Cordis, USA) for transbrachial access. Stenotic segment of renal artery was crossed with 
0.014" guidewire and a cobalt chromium balloon-expandable stent was implanted. A bolus of 5000 IU heparin was administered intra-arterially at the beginning of the intervention. There were no angiographic complications or contrast-induced nephropathy observed. All measurements and laboratory workup were repeated at six-month follow up.

\section{Statistical analysis}

Statistical analysis was performed using SPSS version 20 (IBM, Endicott, NY, USA). The normality of data distribution was tested using Kolmogorov-Smirnov test. Preliminary analyses were performed to ensure no violation of the assumptions of normality, linearity and homoscedasticity. Normally distributed variables were compared using Student's t-tests for unpaired and paired samples, whereas non-normally distributed variables were compared using Mann-Whitney U (unpaired) and Wilcoxon (paired) tests. Baseline-to-follow up comparisons were done using Student's t-test for paired samples and Wilcoxon test. Categorical variables were compared with $\chi^{2}$-tests. ANCOVA was used to compare adjusted means over several groups. Correlations were performed using Pearson correlations for normally distributed and Spearman rho for non-normally distributed variables. Multiple linear regression was used to explore the influence of different variables on survival. A two-tailed test $\mathrm{p}$-value $<0.05$ was considered statistically significant.

\section{Results}

Demographic and clinical characteristics of enrolled patients (mean age $64.3 \pm 10.3$; men 15/48.4\%) are shown in Table 1 . Hypercholesterolemia was present in 29 (93.5\%) patients, $13(41.9 \%)$ patients were smokers, and eight (25.8\%) patients had diabetes. The mean percentage of renal artery stenosis was $82.5 \pm 10.7 \%$ and the mean stenosis length was $11.5 \pm 3.9$ $\mathrm{mm}$. Left and right renal arteries were equally affected (17/16). Stenosis was determined by measuring the ratio between diameter of the narrowest segment of the imaged renal artery and diameter of a normal segment of the artery proximal to the stenosis or distal to poststenotic dilatation. At baseline, all patients with renal artery stenosis received a mean of 4.1 antihypertensive drugs and 2.9 antihypertensive drugs at six-month follow up. The distribution of drugs was as follows: angio-
Table 1. Demographic, clinical and hemodynamic characteristics of all study patients with renal artery stenosis

\begin{tabular}{|c|c|}
\hline & $\mathrm{N}=33$ \\
\hline Age (years) & $64.3 \pm 10.3$ \\
\hline Body mass index $\left(\mathrm{kg} / \mathrm{m}^{2}\right)$ & $27.4 \pm 3.0$ \\
\hline Sex (male) & $15(48.4 \%)$ \\
\hline Hypercholesterolemia (yes) & $29(93.5 \%)$ \\
\hline Smokers (yes) & $13(41.9 \%)$ \\
\hline Ischemic heart disease (yes) & $11(35.5 \%)$ \\
\hline Cerebrovascular disease (yes) & $4(12.9 \%)$ \\
\hline Peripheral arterial disease (yes) & $15(48.4 \%)$ \\
\hline Diabetes (yes) & $8(25.8 \%)$ \\
\hline Degree of stenosis: $\chi \pm \mathrm{SD}(\%)$ & $82.5 \pm 10.7$ \\
\hline $\begin{array}{l}\text { Length of stenotic lesions: } \\
\chi \pm \mathrm{SD}(\mathrm{mm})\end{array}$ & $11.5 \pm 3.9$ \\
\hline Sodium $\mathrm{mmol} / \mathrm{L}$ before & $139.68 \pm 2.63$ \\
\hline Sodium $\mathrm{mmol} / \mathrm{L} 6$ months after & $139.42 \pm 1.51$ \\
\hline Potassium mmol/L before & $4.03 \pm 0.4$ \\
\hline Potassium mmol/L 6 months after & $4.08 \pm 0.29$ \\
\hline Urea $\mathrm{mmol} / \mathrm{L}$ before & $7.23 \pm 2.18$ \\
\hline Urea mmol/L 6 months after & $7.52 \pm 1.7$ \\
\hline Creatinine $\mu \mathrm{mol} / \mathrm{L}$ before & $109.58 \pm 12.37$ \\
\hline Creatinine $\mu \mathrm{mol} / \mathrm{L} 6$ months after & $109.45 \pm 15.12$ \\
\hline $\begin{array}{l}\text { Creatinine clearance corrected } \\
\mathrm{mL} / \mathrm{min} / 1.73 \mathrm{~m}^{2} \text { before }\end{array}$ & $63.89 \pm 21.5$ \\
\hline $\begin{array}{l}\text { Creatinine clearance corrected } \\
\mathrm{mL} / \mathrm{min} / 1.73 \mathrm{~m}^{2} 6 \text { months after }\end{array}$ & $65.09 \pm 17.5$ \\
\hline $\begin{array}{l}\text { Systolic blood pressure before } \\
(\mathrm{mm} \mathrm{Hg})\end{array}$ & $178.7 \pm 20.3$ \\
\hline $\begin{array}{l}\text { Systolic blood pressure } 6 \text { months after } \\
(\mathrm{mm} \mathrm{Hg})\end{array}$ & $154.3 \pm 16.4$ \\
\hline $\begin{array}{l}\text { Diastolic blood pressure before } \\
(\mathrm{mm} \mathrm{Hg})\end{array}$ & $99.5 \pm 13.1$ \\
\hline $\begin{array}{l}\text { Diastolic blood pressure } 6 \text { months } \\
\text { after }(\mathrm{mm} \mathrm{Hg})\end{array}$ & $84.7 \pm 9.2$ \\
\hline Antihypertensive drug number before & $4.1 \pm 0.15$ \\
\hline $\begin{array}{l}\text { Antihypertensive drug number } \\
6 \text { months after }\end{array}$ & $2.9 \pm 0.07$ \\
\hline AIx before & $13.4 \pm 1.1$ \\
\hline AIx 6 months after & $1.1 \pm 0.2$ \\
\hline PWVao before & $13.7 \pm 2.6$ \\
\hline PWVao 6 months after & $12.6 \pm 2.6$ \\
\hline
\end{tabular}

$\mathrm{PWVao}=$ aortic pulse wave velocity; $\mathrm{AIx}=$ augmentation index; results are shown as mean $\pm \mathrm{SD}$ or median (interquartile range) 
Table 2. Demographic, clinical and hemodynamic characteristics of patients with renal artery stenosis (RAS) according to stenosis location

\begin{tabular}{|c|c|c|c|}
\hline & Ostial RAS & Truncal RAS & $\mathrm{p}$ \\
\hline Age (years) & $67.6 \pm 7.5$ & $58.7 \pm 13.1$ & 0.02 \\
\hline Body mass index $\left(\mathrm{kg} / \mathrm{m}^{2}\right)$ & $26.6 \pm 2.7$ & $28.8 \pm 3.1$ & NS \\
\hline Sex male $(\mathrm{n} / \%)$ & $10(43.4 \%)$ & $5(50 \%)$ & NS \\
\hline Hypercholesterolemia yes & $21(91.3 \%)$ & $10(100 \%)$ & NS \\
\hline Smokers yes & $11(47.8 \%)$ & $2(20 \%)$ & NS \\
\hline Ischemic heart disease & $10(43.4 \%)$ & $2(20 \%)$ & NS \\
\hline Cerebrovascular disease & $4(17.3 \%)$ & $0(0 \%)$ & NS \\
\hline Peripheral arterial disease & $15(65.2 \%)$ & $2(20 \%)$ & 0.01 \\
\hline Diabetes & $7(30.4 \%)$ & $2(20 \%)$ & NS \\
\hline Degree of stenosis: $\chi \pm \mathrm{SD}(\%)$ & $81.5 \pm 10.4$ & $84.6 \pm 11.4$ & NS \\
\hline Length of stenotic lesions: $\chi \pm \mathrm{SD}(\mathrm{mm})$ & $11.7 \pm 4.4$ & $10.8 \pm 2.6$ & NS \\
\hline Sodium $\mathrm{mmol} / \mathrm{L}$ before & $139.48 \pm 1.9$ & $140.1 \pm 1.8$ & NS \\
\hline Sodium mmol/L 6 months after & $139.35 \pm 1.7$ & $139.37 \pm 2.1$ & NS \\
\hline Potassium $\mathrm{mmol} / \mathrm{l}$ before & $3.99 \pm 0.3$ & $4.07 \pm 0.5$ & NS \\
\hline Potassium mmol/L 6 months after & $4.07 \pm 0.3$ & $4.10 \pm 0.3$ & NS \\
\hline Urea $\mathrm{mmol} / \mathrm{L}$ before & $7.71 \pm 2.3$ & $6.37 \pm 2.1$ & NS \\
\hline Urea mmol/L 6 months after & $7.84 \pm 1.5$ & $7.04 \pm 2.0$ & NS \\
\hline Creatinine $\mu \mathrm{mol} / \mathrm{L}$ before & $109.70 \pm 23.7$ & $111.60 \pm 30.2$ & NS \\
\hline Creatinine $\mu \mathrm{mol} / \mathrm{L} 6$ months after & $110.91 \pm 19.1$ & $106.80 \pm 26.7$ & NS \\
\hline Creatinine clearance corrected $\mathrm{mL} / \mathrm{min} / 1.73 \mathrm{~m}^{2}$ before & $56.0 \pm 18.2$ & $60.7 \pm 20.0$ & NS \\
\hline Creatinine clearance corrected $\mathrm{mL} / \mathrm{min} / 1.73 \mathrm{~m}^{2} 6$ months after & $54.1 \pm 12.7$ & $62.1 \pm 14.7$ & NS \\
\hline Systolic blood pressure before ( $\mathrm{mm} \mathrm{Hg})$ & $178.0 \pm 19.8$ & $181.1 \pm 21.6$ & NS \\
\hline Systolic blood pressure 6 months after $(\mathrm{mm} \mathrm{Hg})$ & $156.2 \pm 16.8$ & $149.3 \pm 16.3$ & NS \\
\hline Diastolic blood pressure before (mm Hg) & $97.5 \pm 12.7$ & $102.1 \pm 13.4$ & NS \\
\hline Diastolic blood pressure 6 months after $(\mathrm{mm} \mathrm{Hg})$ & $82.3 \pm 9.6$ & $87.1 \pm 11.1$ & NS \\
\hline Antihypertensive drug number before & $4.0 \pm 0.18$ & $3.9 \pm 0.21$ & NS \\
\hline Antihypertensive drug number 6 months after & $2.9 \pm 0.09$ & $2.8 \pm 0.11$ & NS \\
\hline AIx before & $18.0 \pm 1.2$ & $0.81 \pm 0.7$ & NS \\
\hline AIx 6 months after & $4.5 \pm 0.3$ & $-9.3 \pm 1.1$ & NS \\
\hline PWVao before & $14.2 \pm 2.4$ & $12.1 \pm 2.1$ & 0.017 \\
\hline PWVao 6 months after & $13.2 \pm 2.4$ & $10.7 \pm 1.9$ & 0.005 \\
\hline
\end{tabular}

$\mathrm{PWVao}=$ aortic pulse wave velocity; $\mathrm{AIx}=$ augmentation index; results are shown as mean $\pm \mathrm{SD}$ or median (interquartile range); NS = nonsignificant

tensin-converting enzyme (ACE) inhibitors and angiotensin II receptor blockers (ARBs) 30\%, diuretics $100 \%$, Ca-channel blockers $82 \%$, beta blockers $79 \%$, urapidil/moxonidine $88 \%$, and statins $69 \%$. The distribution of drugs at six-month follow up was as follows: ACE inhibitors and ARBs 100\%, diuretics 94\%, Cachannel blockers $36 \%$, beta blockers $27 \%$, urapidil/ moxonidine $42 \%$, and statins $100 \%$. There was no dif- ference in the number and distribution of antihypertensives between the two patient subgroups.

There were no differences in CKD grade 3, diabetes, prior myocardial infarction or stroke prevalence, or in the number of smokers between the two groups of $\mathrm{pa}^{-}$ tients with ostial and truncal renal artery stenosis, but peripheral artery disease was more frequent in the group with ostial renal artery stenosis $(\mathrm{p}=0.01)$ (Table 2$)$. 
After the intervention and at six-month follow up, there was a significant decrease in both systolic and diastolic blood pressure ( $\mathrm{p}<0.05$ both). Both arterial stiffness markers, PWV and AIx, significantly decreased at six-month follow up ( $<<0.05$ both). There were no differences in laboratory parameters and eGFR improvement at six-month follow up. When patients with renal artery stenosis were divided according to sex, laterality of renal artery stenosis, severity of stenosis and eGFR level, no significant differences were found.

When compared to the initial values, PWV at sixmonth follow up was significantly slower in patients with truncal renal artery stenosis and these patients were significantly younger ( $\mathrm{p}<0.05$ both). No differences in AIx values, systolic and diastolic blood pressure, body mass index and laboratory values were found between patients with truncal and ostial renal artery stenosis before and after the intervention ( $>0.05$ all) (Table 2). On univariate analysis, survival was negatively correlated only with age in both patient subgroups $(r=-0.457, p=0.007 ; r=-0.749, p<0.001)$. The impact of intervention on decrease of AIx and PWV values $(p<0.05$ both) was significant in both patient subgroups $(\mathrm{p}<0.05$ both), especially in patients with truncal renal artery stenosis. In the linear regression model, except for age $(\beta=-0.759, \mathrm{p}<0.001)$, PWV before the intervention was the only predictor of shorter survival $(\beta=-2.571, \mathrm{p}=0.023)$.

After the first follow up at six months after the intervention, when all measurements were repeated and the impact of stenting of renal arteries was analyzed, patients were followed-up for a total of 60 months. Twelve patients with ostial and one patient with truncal renal artery stenosis ( $52 \%$ vs. $10 \%, \mathrm{p}<0.001)$ died from cardiovascular events. The causes of cardiovascular deaths in the ostial renal artery stenosis group were stroke $(n=3)$, myocardial infarction $(n=4)$, heart failure $(n=4)$ and aortic dissection $(n=1)$, while one patient from the truncal renal artery stenosis group died from stroke. Out of 12 patients in the truncal renal artery stenosis group, there were eight women and four men ( $66 \%$ vs. $34 \% ; p>0.05$ ). When analyzing the whole group of patients, there was a significantly higher number of patients with lethal event who were suffering from peripheral artery disease compared to surviving patients $(\mathrm{p}=0.01)$, but there were no differences in the number of diabetics, smokers and patients with prior myocardial infarction and stroke ( $p>0.05$ all).

\section{Discussion}

Renal artery stenosis is often an incidental finding in patients undergoing diagnostic evaluation for uncontrolled arterial hypertension or renal failure of unknown origin ${ }^{7,18,19}$. It is diagnosed even more frequently in patients with advanced peripheral arterial disease $^{20,21}$. Compared to general population, a higher prevalence of renal artery stenosis was found in patients with hypertension, ischemic nephropathy and cardiovascular disease, and it is reported that renal artery stenosis is associated with increased mortality as an independent risk factor ${ }^{18,19,22,23}$. Arterial stiffness is an important predictor of future cardiovascular events and all-cause mortality in many subgroups of patients but its role in patients with renal artery stenosis is still unknown. Higher arterial stiffness can additionally increase the already high cardiovascular risk in these patients due to the fact that renal artery stenosis is associated with target organ damage ${ }^{24}$, and is considered a risk factor for mortality. The severity of renal artery stenosis in our group of patients was $>80 \%$, which was similar to the reports from HERCULES study $(81.3 \%)^{25}$, but higher than in CORAL study $(72.5 \%)^{13}$. Technical and procedural effect of the interventions performed was complete, which was similar to many studies $^{26,27}$. There were only two postprocedural complications of pseudoaneurysm formation on femoral artery, which were successfully corrected by surgery. We found no cases of stent-restenosis at 6-month follow up in our patients.

This study showed that endovascular intervention with antihypertensive drugs in the group of patients with renal artery stenosis led to a significant decrease of both arterial stiffness markers, PWV $(-1.1 \pm 2.0 \mathrm{~m} / \mathrm{s}$; $\mathrm{p}<0.01)$ and AIx $(-12.3 \pm 12.2 \% ; \mathrm{p}<0.001)$, at sixmonth follow up. Stenting of renal arteries improved the blood pressure values and its control by decreasing the number of antihypertensive drugs but did not improve renal function. It could be hypothesized that a decrease in AIx values was associated with the reninangiotensin-aldosterone system deactivation due to increased blood flow and decrease in sympathetic activity and peripheral vascular resistance. Although PWV decreased significantly after the intervention, its 
values were still pathologic, probably due to already irreversible structural changes of the large artery walls. In this study, we found that patients with truncal renal artery stenosis had significantly lower PWV values than patients with ostial renal artery stenosis, although there were no differences between these two subgroups in AIx values, systolic and diastolic blood pressure values, and number of antihypertensives. The most plausible explanation of this finding could be a higher incidence of peripheral arterial disease as a marker of subclinical organ damage and obviously more pronounced atherosclerosis, especially in large arteries, accompanied by more advanced chronological age in patients with ostial renal artery stenosis.

Furthermore, a higher percentage of patients with renal artery stenosis and peripheral arterial disease died when compared to patients without peripheral vascular disease, which is in accordance with previous reports by McKenna et al..$^{28}$ and Mui et al. ${ }^{29}$, where peripheral arterial disease per se and accompanied by renal artery stenosis was associated with increased mortality compared to other subgroups of patients. In the whole group and both subgroups of our patients, age and PWV before the intervention were strong and independent predictors of cardiovascular mortality, whereas AIx and both systolic and diastolic blood pressure values were not significant predictors at all. Ostial renal artery stenosis is not just a sign of advanced atherosclerosis of the aorta with its impact on higher PWV values, but is also the cause of higher percentage of fatal cardiovascular events. The overall death percentage of $39.3 \%$ in our group of patients with renal artery stenosis was similar to the results reported by Wright $e t a l^{23}$, and was significantly lower than in other studies ${ }^{22,30}$. Nevertheless, our data suggest that renal artery stenosis has a poor prognosis, especially when accompanied by peripheral vascular disease. In contrast to some studies, we found no significant association of renal failure or severity of renal artery stenosis with increased mortality, but ostial renal artery stenosis as a marker of more pronounced atherosclerosis of large arteries was connected to a higher percentage of cardiovascular mortality at five-year follow up. The most important negative predictor of mortality, except for age, was PWV, confirming our presumption that atherosclerosis of large arteries, expressed as ostial renal artery stenosis, is dependent of PWV and more pronounced when compared to truncal renal artery stenosis.
This is the first study in the available literature that analyzed not only arterial stiffness but also cardiovascular outcome in patients with different location of renal artery stenosis. Endovascular intervention on renal arteries led to a significant decrease in both arterial stiffness markers, AIx and PWV, and to improved blood pressure control with a lower number of antihypertensive drugs. In this longitudinal study, we confirmed our hypothesis and found ostial renal artery stenosis to be a marker of more pronounced atherosclerosis of large arteries.

Our work had several limitations, as follows: 1) we enrolled a relatively small number of patients and therefore we cannot extrapolate these results to all $\mathrm{pa}-$ tients with renal artery stenosis; 2) secondly, before the intervention, patients were treated with different classes and combinations of antihypertensive drugs, whereas afterwards all patients were treated with ACE inhibitors or ARBs and we cannot exclude the possible impact of these differences; 3 ) we did not enroll a control, healthy or hypertensive group of patients without renal artery stenosis; 4) we did not analyze renin and aldosterone levels in serum, which are elevated in patients with renal artery stenosis and therefore associated with progression of systemic atherosclerosis; and 5) PWV was determined using Arteriograph, a device which is validated but with no reference cut-off values for patients with renal artery stenosis.

\section{Conclusions}

The impact of endovascular intervention on renal arteries leads to a significant decrease in both arterial stiffness markers, AIx and PWV, and to improved blood pressure control with a lower number of antihypertensive drugs. The higher incidence of peripheral arterial disease and cardiovascular mortality found in patients with ostial renal artery stenosis is most likely due to more pronounced atherosclerosis of large arteries and is accelerated with age.

\section{References}

1. Jacobson HR. Ischemic renal disease: an overlooked clinical entity? Kidney Int. 1988;34:729-43.

2. Valentine RJ, Myers SI, Miller GL, et al. Detection of unsuspected renal artery stenoses in patients with abdominal aortic aneurysms: refined indications for preoperative aortography. 
Ann Vasc Surg. 1993;7:220-4. https://doi.org/10.1007/BF0 2000245

3. Olin JW, Melia M, YoungJR, et al. Prevalence of atherosclerosis renal artery stenosis in patients with atherosclerosis elsewhere. Am J Med. 1990;88:46-51.

4. Crowley JJ, Santos RM, Peter RH, et al. Progression of renal artery stenosis in patients undergoing cardiac catheterization. Am Heart J. 1998;136:913-8.

5. Caps MT, Perissinotto C, Zierler RE, et al. Prospective study of atherosclerotic disease progression in the renal artery. Circulation. 1998;98:2866-72.

6. Olin JW. Atherosclerotic renal artery disease. Cardiol Clin. 2002;20:547-62.

7. Conlon PJ, Little MA, Pieper K, et al. Severity of renal vascular disease predicts mortality in patients undergoing coronary angiography. Kidney Int. 2001;60:1490-7. https://doi.org/ 10.1046/j.1523-1755.2001.00953.x

8. Laurent S, Boutouyrie P. Arterial stiffness: a new surrogate endpoint for cardiovascular disease? J Nephrol. 2007;20(12): 45-50.

9. Vlachopoulos C, Aznaouridis K, Stefanadis C. Prediction of cardiovascular events and all-cause mortality with arterial stiffness: a systematic review and meta-analysis. J Am Coll Cardiol. 2010;55:1318-27. https://doi.org/10.1016/j.jacc.2009.10.061

10. Vlachopoulos C, Aznaouridis K, O'Rourke MF, et al.Prediction of cardiovascular events and all-cause mortality with central haemodynamics: a systematic review and meta-analysis. Eur Heart J. 2010;31:1865-71. https://doi.org/10.1093/eurheartj/ ehq024

11. Fodor L, Premužić V, Ivković V, et al. Arterial stiffness in atherosclerotic renovascular hypertension. J Hypertens. 2014;32(11): 2238-45. https://doi.org/10.1097/HJH.0000000000000324

12. Mui KW, Sleeswijk M, van den Hout $\mathrm{H}$, et al. Incidental renal artery stenosis is an independent predictor of mortality in patients with peripheral vascular disease. J Am Soc Nephrol. 2006;17:2069-74. https://doi.org/10.1681/ASN.2005080827

13. Cooper C, Murphy T, Cutlip D, et al. CORAL Investigators. Stenting and medical therapy for atherosclerotic renal-artery stenosis. N Engl J Med. 2014;370:13-22. https://doi. org/10.1056/NEJMoa1310753

14. Textor S, Misra S, Oderich G. Percutaneous revascularization for ischemic nephropathy: the past, present, and future: Kidney Int. 2013;83:28-40. https://doi.org/10.1038/ki.2012.363

15. Rocha-Singh K, Eisenhauer A, Textor S, et al. American Heart Association Writing Group 8. Atherosclerotic Peripheral Vascular Disease Symposium II: Intervention for renal artery disease. Circulation. 2008;118:2873-8. https://doi.org/10.1161/ CIRCULATIONAHA.108.191178

16. van Jaarsveld BC, Krijnen P, Pieterman H, et al. The effect of balloon angioplasty on hypertension in atherosclerotic renalartery stenosis. Dutch Renal Artery Stenosis Intervention Cooperative Study Group. N Engl J Med. 2000;342:1007-14. https://doi.org/10.1056/NEJM200004063421403
17. Goldblatt H, Lynch J, Hanzal RF, et al. Studies on experimental hypertension: production of persistent elevation of systolic blood pressure by means of renal ischemia. J Exp Med. 1934; 59:347-79. https://doi.org/10.1084/jem.59.3.347

18. Kalra PA, Guo H, Kausz AT, et al. Atherosclerotic renovascular disease in United States patients aged 67 years or older: risk factors, revascularization, and prognosis. Kidney Int. 2005;68: 293-301. https://doi.org/10.1111/j.1523-1755.2005.00406.x

19. Wright JR, Shurrab AE, Cooper A, et al. Left ventricular morphology and function in patients with atherosclerotic renovascular disease. J Am Soc Nephrol. 2005;16:2746-53. https://doi. org/10.1681/ASN.2005010043

20. Leertouwer TC, Pattynama PM, van den Berg-Huysmans A. Incidental renal artery stenosis in peripheral vascular disease: a case for treatment? Kidney Int. 2001;59:1480-3. https://doi. org/10.1046/j.1523-1755.2001.0590041480.x

21. Pillay WR, Kan YM, Crinnion JN, et al. Prospective multicentre study of the natural history of atherosclerotic renal artery stenosis in patients with peripheral vascular disease. Br J Surg. 2002; 89:737-40. https://doi.org/10.1046/j.1365-2168.2002.02144.x

22. Isles C, Main J, O'Connell J, et al. Survival associated with renovascular disease in Glasgow and Newcastle: a collaborative study. Scott Med J. 1990;35:70-3. https://doi.org/10.1177/ 003693309003500303

23. Wright JR, Shurrab AE, Cheung C, et al. A prospective study of the determinants of renal functional outcome and mortality in atherosclerotic renovascular disease. Am J Kidney Dis. 2002; 39:1153-61. https://doi.org/10.1053/ajkd.2002.33384

24. Novick AC, Pohl MA, Schrieber M, et al. Revascularization for preservation of renal function in patients with atherosclerotic renovascular disease. J Urol. 1983;129:907-12.

25. Jaff MR, Bates M, Sullivan T, et al. HERCULES Investigators. Significant reduction in systolic blood pressure following renal artery stenting in patients with uncontrolled hypertension: results from the HERCULES trial. Catheter Cardiovasc Interv. 2012;80(3):343-50. https://doi.org/10.1002/ccd.24449

26. Sekkarie M. Treatment of renal artery stenosis by invasive procedures. Am J Kidney Dis. 1999;33(3):613-4.

27. Burket MW, Cooper CJ, Kennedy DJ, et al. Renal artery angioplasty and stent placement: predictors of a favorable outcome. Am Heart J. 2000;139(1):64-71.

28. McKenna M, Wolfson S, Kuller L. The ratio of ankle and arm arterial pressure as an independent predictor of mortality. Atherosclerosis. 1991;87:119-28.

29. Mui KW, Zeebregts CJ, van den Hout $\mathrm{H}$, et al. Impact of incidental renal artery stenosis on long-term mortality in patients with peripheral arterial disease undergoing vascular procedure. J Vasc Surg. 2011;54(3):785-90. https://doi.org/10.1016/j. jvs.2011.03.251

30. Wollenweber J, Sheps SG, Davis GD. Clinical course of atherosclerotic renovascular disease. Am J Cardiol. 1968;21: 60-71. 
Sažetak

\title{
USPOREDBA OSTIJALNOG I TRUNKALNOG SUŽENJA BUBREŽNE ARTERIJE: PREDIKTOR POŠIRENOSTI ATEROSKLEROZE VELIKIH ARTERIJA I VEĆE SMRTNOSTI
}

\author{
D. Perkor, V. Premužic, R. Smiljanic, Lj. Fodor, S. Dobrota i B. Jelaković
}

Cilj ovog istraživanja bio je utvrditi krutost arterija i učinak stentiranja u bolesnika sa suženjem bubrežne arterije. Hipoteza je bila da ostijalno suženje bubrežne arterije nije samo pokazatelj izraženije ateroskleroze velikih arterija, nego je i prediktor veće kardiovaskularne smrtnosti. $U$ istraživanje smo uključili 33 bolesnika sa suženjem bubrežne arterije koji su bili refraktorni na farmakološko liječenje i podijelili ih prema položaju suženja bubrežne arterije, ostijalnom i trunkalnom (23 naspram 10 bolesnika). Analizirali smo preživljenje bolesnika nakon petogodišnjeg praćenja. Neposredno nakon intervencije i šest mjeseci nakon intervencije došlo je do značajnog smanjenja vrijednosti krvnog tlaka, kao i brzine pulsnog vala (PWV) $\mathrm{i}$ indeksa augmentacije. Brzina pulsnog vala (pulse wave velocity, PWV) je bila značajno niža u bolesnika s trunkalnim suženjem arterije i ti su bolesnici bili značajno mlađi. Dvanaest bolesnika s ostijalnom i jedan bolesnik s trunkalnim suženjem bubrežne arterije $(52 \%$ naspram $10 \%, \mathrm{p}<0,001)$ umrlo je od kardiovaskularnih događaja. Naša studija je prva koja potvrđuje prediktivnu ulogu PWV i arterijske krutosti u bolesnika sa suženjem bubrežne arterije, osobito ostijalnim, te naglašava njezinu sposobnost otkrivanja buduće veće incidencije kardiovaskularnih događaja.

Ključne riječi: Bubrežna arterija, opstrukcija; Ateroskleroza; Pulsni val, analiza; Vaskularna krutost; Mortalitet; Preživljavanje 